Marot, Didier; Sail, Y.; Alexis, A.

Experimental Bench for Study of Internal Erosion in Cohesion less Soils

Verfügbar unter / Available at:

https://hdl.handle.net/20.500.11970/100304

Vorgeschlagene Zitierweise / Suggested citation:

Marot, Didier; Sail, Y.; Alexis, A. (2010): Experimental Bench for Study of Internal Erosion in Cohesion less Soils. In: Burns, Susan E.; Bhatia, Shobha K.; Avila, Catherine M. C.; Hunt, Beatrice E. (Hg.): Proceedings 5th International Conference on Scour and Erosion (ICSE-5), November 7-10, 2010, San Francisco, USA. Reston, Va.: American Society of Civil Engineers. S. 418-427. 


\title{
Experimental Bench for Study of Internal Erosion in Cohesionless Soils
}

\author{
D. Marot, Y. Sail and A. Alexis
}

University of Nantes, Institut GeM, BP 42044606 Saint-Nazaire Cedex, France; email : didier.marot@univ-nantes.fr, yacine.sail@univ-nantes.fr, alain.alexis@univnantes.fr

\begin{abstract}
Under the internal flow, hydraulic earth structures (dikes, levees, or dams) can incur a migration of particles that can induce a modification of hydraulic and mechanic characteristics.

With the objective to characterize this phenomenon named internal erosion and its consequences on mechanical behaviour of granular materials, a large oedopermeameter device is developed. An axial load is applied on specimen and also a downward flow with a constant hydraulic gradient. During the testing time, the bench can measure the spatial variability of density and of interstitial pressure along the specimen. Axial deformation, injected flow and eroded mass are also measured during the testing time.

Erosion of fine particles on downstream specimen part is accompanied by fine particles migration in the specimen. This migration induces a settlement and an increasing of interstitial pressure. Afterwards a localized instability appears and triggers specimen deformation.
\end{abstract}

\section{INTRODUCTION}

Within earth structure such as dam, dike or levee, seepage can induce a detachment and a transport of fine particles from the structure or from its foundation. This process named internal erosion can modify hydraulic properties of soil as permeability but internal erosion can also modify mechanical behaviour. Finally these modifications can induce instability of the earth structure. The occurrence of failures in new earth structures demonstrates the need of improving the knowledge of these phenomena and its consequences on mechanical behaviour of soil.

In uncracked soils, the two main phenomena of internal erosion are suffusion and backward erosion. Suffusion is the detachment and transport process of only fine particles whereas backward erosion concerns all grains. Initiation of internal erosion processes is influenced by geometric conditions as grain size distribution, porosity of soil (Kenney and Lau, 1985) and grain shape (Li, 2008) and by loading conditions as effective stress (Li, 2008) and hydraulic gradient (Skempton and Brogan, 1994). Depending on the process of internal erosion, confinement stress has a complex effect on internal erosion development (Bendahmane et al., 2008).

A new experimental bench is developed in order to characterize initiation and development of internal erosion. This device is described and a test procedure is performing for a specimen composed by a gap gradation of glass beads. Hydraulic and mechanical response of the specimen to an increasing hydraulic gradient is presented. 


\section{OEDO-PERMEAMETER DEVICE}

The main bench characteristics are summarized in Figure 1. Device is configured to enable specimen preparation which is saturated and consolidated in oedometric condition. Specimen is subjected to seepage flow under a hydraulic gradient that increases by stages.

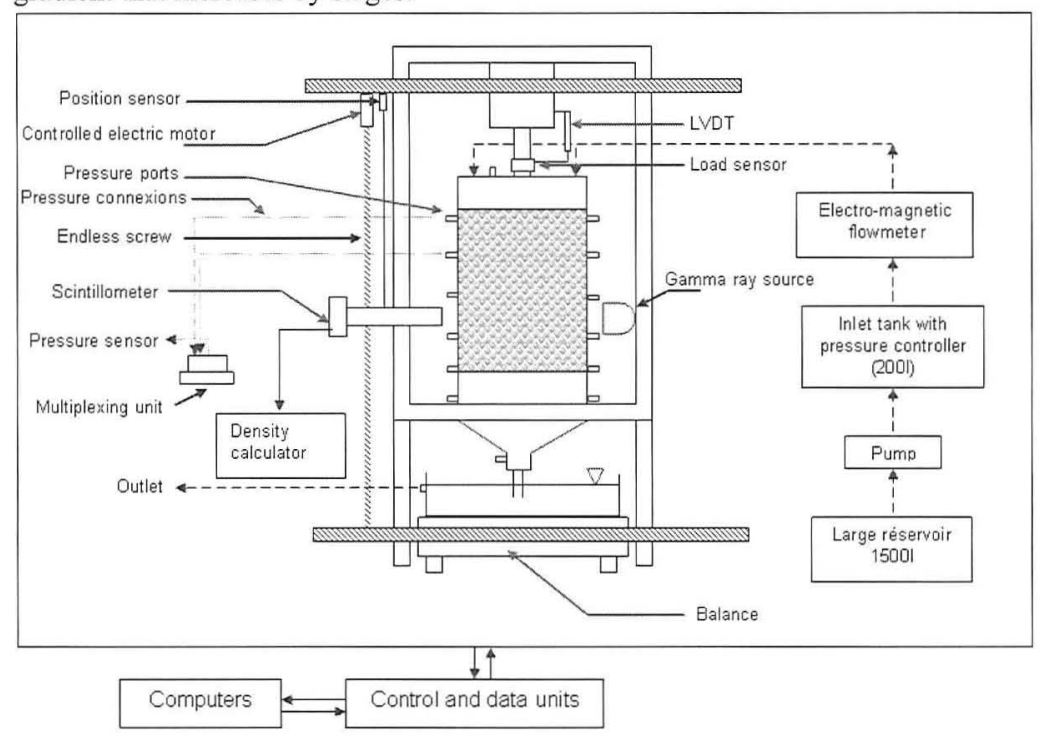

Figure 1. Schematic diagram of oedo-permeameter device

The bench is composed of an oedo-permeameter cell with a funnel-shaped draining system which is connected to a collection system. The bench comprises also an axial loading system, a hydraulic control system and a gammadensitometric system. The control and acquisition part is provided by two units connected to two computers. All these components are detailed below.

\section{Oedo-permeameter cell}

With the aim to observe specimen during testing time, the rigid wall cell is made of Plexiglas tube. Internal cell diameter is $\Phi_{\text {cell }}=275 \mathrm{~mm}$ and the specimen height can reach $600 \mathrm{~mm}$. It can be noted that oedo-permeameter cell allows testing specimen with a maximum grain size $D_{\max }=9 \mathrm{~mm}$ (equivalent to a cell factor $\mathrm{D}_{\max } / \Phi_{\text {cell }}=30$ ) and a slenderness ratio of 2 . The two ends of Plexiglas tube are reinforced by stainless steel plate. Cell wall is equipped with twelve pressure ports (two arrays of six pressure ports on opposite cell sides, two by two pressure ports at the same elevation and vertical spacing of $100 \mathrm{~mm}$ between pressure ports), a pressure port is placed on piston base plate (see below axial loading system) and a fourteenth port is positioned below specimen on draining system. In order to avoid 
discrepancy between two pressure transducers, pressure ports are connected to a multiplex unit which is connected to a pressure sensor (Alexis et al, 2004).

Thanks to several specimen supports, specimen with different heights can be tested. A stainless steel mesh screen is placed on specimen support. This $15 \mathrm{~mm}$ thick mesh screen has $10 \mathrm{~mm}$ pore opening size in order to allow the migration of all grains. With a rim, different wire meshes can be fixed on the mesh screen in order to take into account the effect of pore opening size on internal erosion (Marot et al, 2009). To eliminate any preferential flow between mesh screen and cell, a geotextile is placed between wire screen edge and rigid wall of cell.

Top plate has two inlet ports $10 \mathrm{~mm}$ in diameter and the base plat has a vertical funnel-shaped draining system which is specially designed to avoid clogging. The opening of draining system is controlled by a pneumatic gate. Outlet pipe is in glass in order to permit the measurement of effluent transparency by means of an optical sensor (Bendahmane et al., 2008).

\section{Collection system}

The collection system is composed of an effluent tank which has an overflow outlet with a $0.08 \mathrm{~mm}$ mesh in order to catch the fine eroded particles. Effluent tank can be continuously weighing or can contain several beakers for the effluent sampling.

\section{Axial loading system}

A piston, a pneumatic cylinder and a reaction frame compose the axial loading system. Piston comprises two perforated plates which are made of $15 \mathrm{~mm}$ thick stainless steel. A $61 \mathrm{~mm}$ thick layer of gravel separates the two plates in order to diffuse the injected fluid on the specimen contact interface uniformly. Two joints are bonded to the piston edge to avoid any parasitic particle displacements between piston and cell wall.

Axial effective stress on the top surface of specimen is generated by a pneumatic cylinder (capacity: $11.5 \mathrm{kN}$ ) which has a $200 \mathrm{~mm}$ stroke in order to maintain the axial stress even in the case of a great specimen settlement. A load cell measures the axial force on the loading rod. The piston displacements and thus the specimen settlements are measured by a Linear Variable Differential transducer (LVDT) (stroke: $200 \mathrm{~mm}$ ).

The pneumatic cylinder is mounted on a framework. This framework supports also the oedo-permeameter cell which is mounted on a large ball bearing for the axial cell rotation.

\section{Hydraulic control system}

Hydraulic system is composed of two reservoirs and a pump. A 1500 litre storage reservoir is supplied by public water system and placed in a temperaturecontrolled chamber. 
With a pump, this reservoir supplies a $200 \mathrm{~L}$ tank which is equipped with a pressure controller. A pressure transducer connected to the pressure port on the piston base plate allows controlling the water head applied on specimen top face. The connexion between controlled pressure tank and eodo-permeameter cell includes two electromagnetic flowmeters $(120 \mathrm{~L} / \mathrm{min}$ and $480 \mathrm{~L} / \mathrm{min}$ of capacity) for the measurement of seepage flow.

\section{Gamma-densitometric system}

The gammadensitometric bench was developed by Alexis et al. (2004). It comprises a radioactive gamma-ray source and a scintillation counter on the opposite cell side. These components are bonded on a carriage which can move in vertical direction thanks to an endless screw and a controlled electric motor. The position of the carriage is measured by a position transducer. According to a previous gauging data, a density calculator counts the scintillometer impulses and calculates the density.

\section{Monitoring and data acquisition system}

The control and acquisition part is provided by two data units. One principally controls the gammadensitometric bench motor and the multiplex unit. It is also in charge of the acquisition of: density measurements, position carriage and water head. Two velocities of travelling motion are used, a cruising speed and an approach speed to limit both travelling duration and position discrepancy. This unit drives the run of the second data acquisition unit.

The second data unit carries out the measurements from load sensor, settlement sensor, mass balance and seepage flowmeters.

\section{TEST PROCEDURE AND TESTED MIXTURE PROPERTIES}

The tested material is a mixture of glass beads. This cohesionless material allows to compare our results with an experimental campaign performed by Moffat and Fannin (2006) with a large permameter.

\section{Grain size distribution of mixture}

Figure 2 plots the grain size distribution of tested mixture (named G4-C by Moffat and Fannin, 2006) and the grain size distributions of the mixture components (coarse fraction $\mathrm{C}$ and fine fraction $\mathrm{F}$ ). 


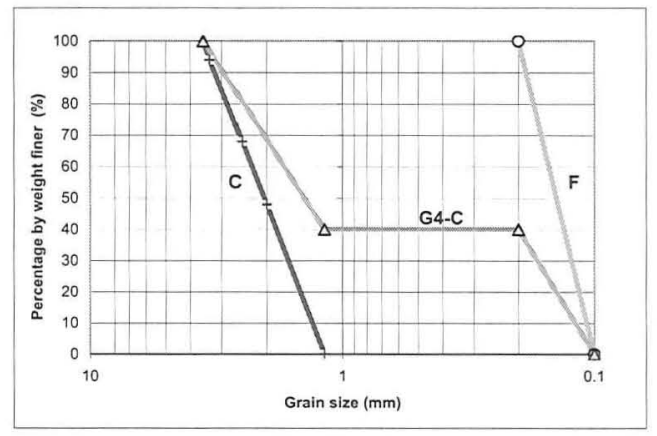

Figure 2. Grain size distribution of tested mixture.

According to Moffat and Fannin (2006), fine fraction $\mathrm{F}$ is equivalent to fine sand with a coefficient of uniformity $\mathrm{Cu}=1.4$ and $\mathrm{d}_{85}=0.19 \mathrm{~mm}$ (where $\mathrm{d}_{85}$ : sieve size for which $85 \%$ of the weighed soil is finer). Fraction $\mathrm{C}$ is equivalent to coarse sand with $\mathrm{Cu}=1.7$ and $\mathrm{d}_{10}=1.4 \mathrm{~mm}$. Gradation $\mathrm{G} 4-\mathrm{C}$ is composed of $40 \%$ by weight of $\mathrm{F}$ and $60 \%$ of $\mathrm{C}$ and it is characterized by a gap. The mixture preparation phase is divided in four steps: positioning alternatively a series of coarse and fine fractions layers in mixing machine with $10 \%$ of water content, mixing during 3 minutes and homogeneity verification by size distribution measurements.

\section{Test procedure}

A wire mesh with a $1.25 \mathrm{~mm}$ pore opening size is fixed on wire mesh screen in order to allow only the migration of particles $\mathrm{F}$.

The cell is filled with water to saturate by gravity flow: the pressure connexions, the multiplex unit and the pressure sensor.

In conformity with specimen reconstitution technique used by Moffat and Fannin (2006), specimen is prepared in several layers by slurry deposition. The total dry mass of glass beads in specimen is $51.64 \mathrm{~kg}$ and the initial specimen height is $45 \mathrm{~cm}$. An upper wire mesh of $0.08 \mathrm{~mm}$ is placed on specimen face to avoid fine particles migration in the piston. Specimen consolidation occurs under $25 \mathrm{kPa}$ axial loading and with double drainage condition (dissipation of excess interstitial pressure in upward and downward direction).

Data acquisition is started afterwards specimen is submitted to a downward seepage under a first value of hydraulic gradient. Hydraulic gradient is increased by increments about unity until specimen failure. Each stage of hydraulic gradient is applied during 60 minutes. During testing duration, data are recorded with a periodicity of 1 second and the effluent sampling is performed with a 6 minutes period.

For this specimen height, Figure 3 shows the position of used pressure ports (number 1 to 11 ) and the distance from the specimen bottom of density measurement stations (section 1 to section 6). 
At the end of each hydraulic gradient stage, the specimen is isolated by simultaneous closing of upstream and downstream gates and the controlled pressure tank is filled.

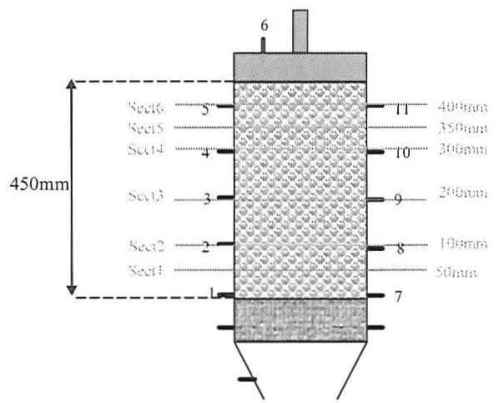

Figure 3. Position of interstitial pore pressure ports and stations of density measurement.

\section{TEST RESULTS AND DISCUSSION}

Moffat and Fannin (2006) detected the onset of failure for a value of hydraulic gradient $i=8.3$. About half of this value was chosen for the first stage of hydraulic gradient $(i=3.6)$ and two other stages could be applied on specimen before failure: 4.6 and 5.6 respectively.

\section{Initial state of specimen}

At the end of specimen preparation, a loss of fine particles is measured which represents around $2.7 \%$ of total fine mass. The upward and downward profiles of density measurement (cf. Figure 4) show a density which decreases in downward direction from $2 \mathrm{~g} / \mathrm{cm}^{3}$ to $1.95 \mathrm{~g} / \mathrm{cm}^{3}$.

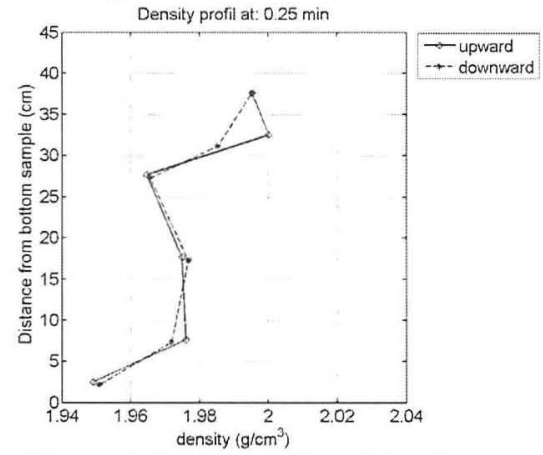

Figure 4. Initial profiles of density. 
The low discrepancy between these two density profiles shows that repeatability of density measurement is fairly good as the two profiles are very close.

\section{Injected flow and permeability}

During the first hydraulic gradient stage $\left(i_{1}=3.6\right)$, the seepage flow is $1.3 \mathrm{~L} / \mathrm{min}$. For the second stage $\left(i_{2}=4.6\right)$, the flow reaches $1.7 \mathrm{~L} / \mathrm{min}$ and its value is $2 \mathrm{~L} / \mathrm{min}$ during 20 minutes of third stage $\left(i_{3}=5.6\right)$. For these three stages, the specimen hydraulic conductivity is $\mathrm{k}=1.10^{-4} \mathrm{~m} / \mathrm{s}$.

At $\mathrm{t}=20 \mathrm{~min}$ for the third stage, flow suddenly increases and finally it exceeds the flowmeter capacity ( $>8 \mathrm{~L} / \mathrm{min}$ ). So the specimen hydraulic conductivity is higher than $4.10^{-4} \mathrm{~m} / \mathrm{s}$. An instability characterized by no particle $\mathrm{F}$ can be observed along the cell (see Figures 5(a) and 5(b)).

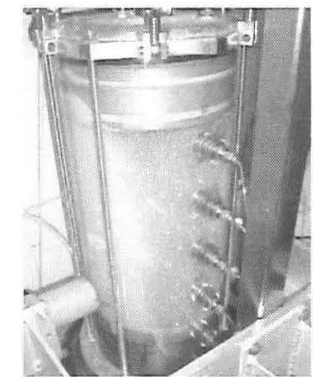

(a)

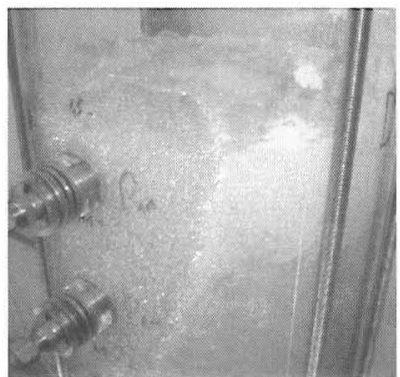

(b)

Figure 5. Localized instability: (a) general view, (b) detail near pore pressure ports number 11 and $10\left(i_{3}=5.6 \mathrm{~m} / \mathrm{m}, \mathrm{t}>20 \mathrm{~min}\right)$.

The initiation of this instability is observed at the specimen top interface and it progresses in downstream direction along the positions of pressure ports number $11,10,9,8$ and finally 7 .

\section{Eroded mass and settlement}

Application of the two first stages of hydraulic gradient induces a small erosion of fine particles (for $i_{1}=3.6$, eroded mass $m_{F \text { eroded }}=140 \mathrm{~g}$, that represents a relative erosion $\mathrm{m}_{\mathrm{F} \text { eroded }} / \mathrm{m}_{\text {Finitial }}=0.7 \% ;$ for $\quad \mathrm{i}_{2}=4.6, \quad \mathrm{~m}_{\mathrm{F} \text { eroded }}=250 \mathrm{~g}$, $\mathrm{m}_{\mathrm{F} \text { eroded }} / \mathrm{m}_{\text {Finitial }}=1.2 \%$ ).

The measured settlements are similar for the two stages: for each stage around $2.4 \mathrm{~mm}$ (that corresponds to a $0.5 \%$ axial deformation).

During the first twenty minutes of the third stage $\left(i_{3}=5.6\right.$ ) (which corresponds to the first fifteen minutes of effluent sampling) the increasing of settlement is quite similar to the settlement increasing in the course of previous stages and eroded mass is $\mathrm{m}_{\mathrm{F} \text { eroded }}=200 \mathrm{~g}\left(\mathrm{~m}_{\mathrm{F} \text { eroded }} / \mathrm{m}_{\text {Finitial }}=0.9 \%\right)$. At $\mathrm{t}=20 \mathrm{~min}$, 
settlement suddenly increases to reach $13 \mathrm{~mm}$ (axial deformation of 3\%) and the cumulative eroded mass increases by $2.4 \mathrm{~kg}\left(\mathrm{~m}_{\mathrm{F} \text { eroded }} / \mathrm{m}_{\text {Finitial }}=11 \%\right)$.

Figure 6 represents the instantaneous variations of eroded mass and settlement during the three stages.

$\mathrm{i}=3.6$

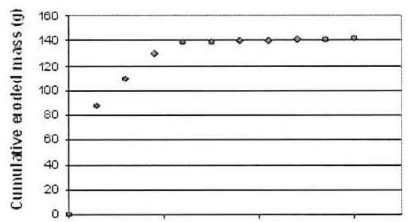

$\mathrm{i}=4.6$

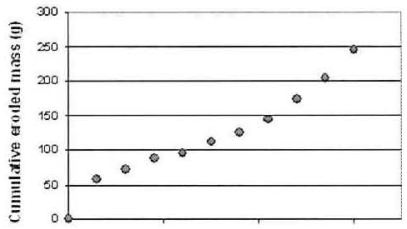

$i=5.6$

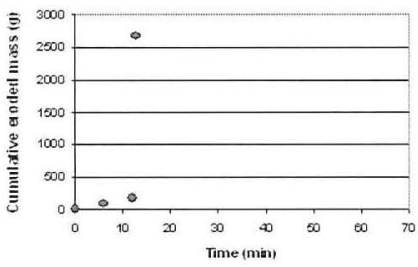

(a)
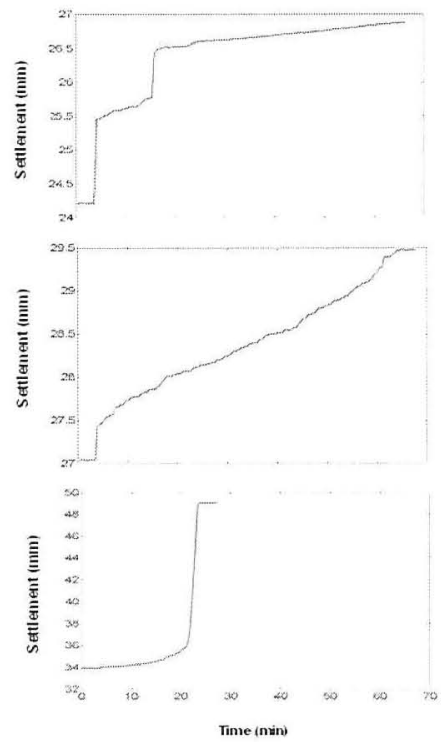

(b)

Figure 6. Instantaneous variations of: (a) eroded mass, (b) settlement during the three stages.

It can be noted the similar kinetics of increasing for eroded mass and settlement. Two hypotheses about the process can be considered:

-fine particles erosion at specimen bottom induces a migration of fine particles which concerns the whole specimen and causes the settlement

-fine particles erosion at specimen bottom induces an instability located on downstream part and which causes a specimen translation without any migration of fine particle in the specimen centre.

\section{Density variations}

Two types of density variations are measured during the two first stages of hydraulic gradient:

-decrease of density in the downstream part of specimen (sections 1,2 and 3) with a relative variation in comparison to initial density between $-0.5 \%$ and $-1.5 \%$ 
-increase of density in the upstream part (sections 5 and 6) with a relative variation between $+0.25 \%$ and $+2.4 \%$.

During the third stage, only the density values on downstream part evolve $(-1 \%$ for sections 1,2 and 3$)$. It must be noted that the localized instability was developed outside of the measurement zone of gammadensitometer (see Figure 5(a)).

\section{Local hydraulic head variations}

Spatial and time evolutions of local hydraulic head during hydraulic gradient stages 1 and 2 don't evolve significantly.

Figure 7 represents profiles of hydraulic head during the third stage. At $\mathrm{t}=5 \mathrm{~min}$ hydraulic head decreases because of the downstream gate opening. At $\mathrm{t}=10 \mathrm{~min}$, the hydraulic head on pressure port number 11 slightly increases. 5 minutes later, a fast increasing of hydraulic head on pressure port number 10 of about $\Delta \mathrm{h}_{10}=35 \mathrm{~cm}$ is detected (that corresponds to an overpressure of $3.5 \mathrm{kPa}$ ).

At $\mathrm{t}=17 \mathrm{~min}$ the hydraulic head on point 9 increases about $\Delta \mathrm{h}_{9}=55 \mathrm{~cm}$ and one minute later on point $8: \Delta \mathrm{h}_{8}=20 \mathrm{~cm}$. This increasing of interstitial pressure which appears in the specimen centre and progresses in downstream direction may be due to clogging. At $\mathrm{t}=20 \mathrm{~min}$, hydraulic head profiles decrease suddenly and this evolution appears at the same time as increasing of: seepage flow, settlement and eroded mass.

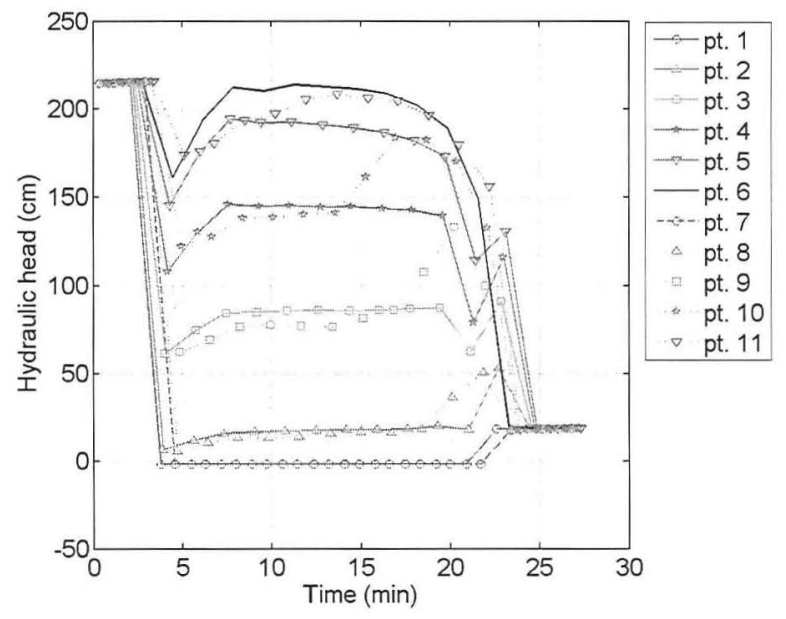

Figure 7. Instantaneous variations of hydraulic head (during third stage). 
Thus a clogging which induces an interstitial overpressure appears (at point 10) 5 minutes before the initiation of localized instability. This observation confirms the first hypothesis of a fine particles migration in the whole specimen.

\section{CONCLUSION}

An experimental bench is designed to study initiation and development of internal erosion and its consequences on the hydraulic and mechanical behaviour of cohesionless soils. The device and experimental procedure are detailed. Results of a test performed on gap graded glass beads specimen are reported. On the downstream specimen part, an erosion of fine particles is detected and causes a migration of fine particles in the whole specimen. This evolution induces specimen settlement and a localized interstitial overpressure. This overpressure may be due to clogging and may be the cause of a localized instability. Finally the hydraulic conductivity is four times higher and the axial deformation reaches $4 \%$.

The experiment setup could be used on different soils with varying particle fractions, in order to improve our understanding of the internal erosion mechanism.

\section{ACKNOWLEDGEMENT}

The authors wish to acknowledge the support of the French National Research Agency (project ANR-ERINOH) and the support of the French Institute for Applied Research and Experimentation in Civil Engineering (IREX) for this research.

\section{BIBLIOGRAPHY}

Alexis A., Le Bras G., Thomas P. (2004)."Experimental bench for study of settlingconsolidation soil formation." Geotechnical Testing J. 27 (6): 557-567.

Bendahmane F., Marot D., Alexis A. (2008). "Parametric study of suffusion and backward erosion." J. of Geotechnical and Geoenvironmental Engineering (ASCE), 134 (1): 57-67.

Kenney T.C., Lau D. (1985). "Internal stability of granular filters." Canadian Geotechnical J. 22 (2): 215-225.

Li M. (2008). "Seepage induced instability in widely graded soils." PhD Thesis, University of British Colombia, Vancouver, Canada, $300 \mathrm{p}$.

Marot D., Bendahmane F., Rosquoet F. Alexis A. (2009). "Internal flow effects on isotropic confined sand-clay mixtures." Soil \& Sediment Contamination, an Int. J. 18 (3): 557-567.

Moffat R., Fannin R.J. (2006). “A large permeameter for study of internal stability in cohesionless soils." Geotechnical Testing J. 29 (4): 1-7.

Skempton A.W., Brogan J.M. (1994). "Experiments on piping in sandy gravels." Géotechnique 44 (3): 449-460. 